\title{
Cornelis Norbertus Gijsbrechts og Kunstkammerets Perspectiv Kammer
}

\author{
EVA DE LA FUENTE
}

Med øjenbedraget som mål udførte den flamske maler Cornelis Norbertus Gijsbrechts (-1659-1675-) en serie trompe l'oeiler for Frederik III og Christian V mellem 1668 og 1672. Mange af dem endte på Kunstkammeret. Var det resultatet af en på forhånd planlagt strategi, eller var det et tilfælde? Kan de tidligste inventarier fra 1674 og 1690 give svar på, hvilke af Gijsbrechts' malerier, der kan have været udstillet $\mathbf{i}$ Kunstkammeret og hvilke andre værker, de var i selskab med? Udgjorde de tilsammen en meningsfuld helhed? Hvis det er tilfældet, hvad var så den dybere mening med, at Gijsbrechts' trompe l'oeiler blev del af Kunstkammeret?

Den danske senbaroks største arkitekt, Laurids de Thurah, gav i sit store værk om København, Hafnia Hodierna, fra 1748, en af de første trykte beskrivelser af Kunstkammeret og den nye bygning, som Frederik III i 1665 begyndte opførelsen af ved Københavns Slot. Der skulle ikke alene skaffes plads til Kunstkammeret, men også til tøjhusets våbensamling og kongens bibliotek. Laurids de Thurah skriver:

Næst ved Proviant-Gaarden er imellem de tvende Slottets Løngange det store og anseelige Huus, hvorudi findes det vidt berømte Kongelige Kunst-Kammer og det Kongelige Bibliotheque.....Jeg veed ey noget Bibliotheque, i Henseende til Indretningen at ligne dette bedre, end det bekiendte og berømte herlige saa kaldede Biblioteca della Minerva i Rom. Til dette har høysalig kong Friderich den Tredie, som er bekiendt for en af vore lærdeste Konger, lagt den første Grundvold... (Thura 1748:107f.)

Fra biblioteket fører Laurids de Thura sin læser op til Kunstkammeret på anden sal:

Fra Trappen træder man først ind i et Forkammer, som fører Navn af Perspectiv-Kammer, fordi deri findes adskillige Skabe, hvorudi alle Arter af Kirker, Lutherske, Reformerede, og Romersk-Catholske og andre Ting kunstig i Perspectiv forestilles. Man seer her og en Mængde af Malerier i Perspectiv kunstig udførte; og adskillige andre med still-liggende Sager, som Malerne kalde det; disse sidste ere især af en berømt Mester, navnlig Gysbrect, og andre navnkundige Mænd forfærdigede.....

Hidtil har man ikke set en dybere mening med Perspectiv Kammerets udsmykning. 


\section{EVA DE LA FuENTE}

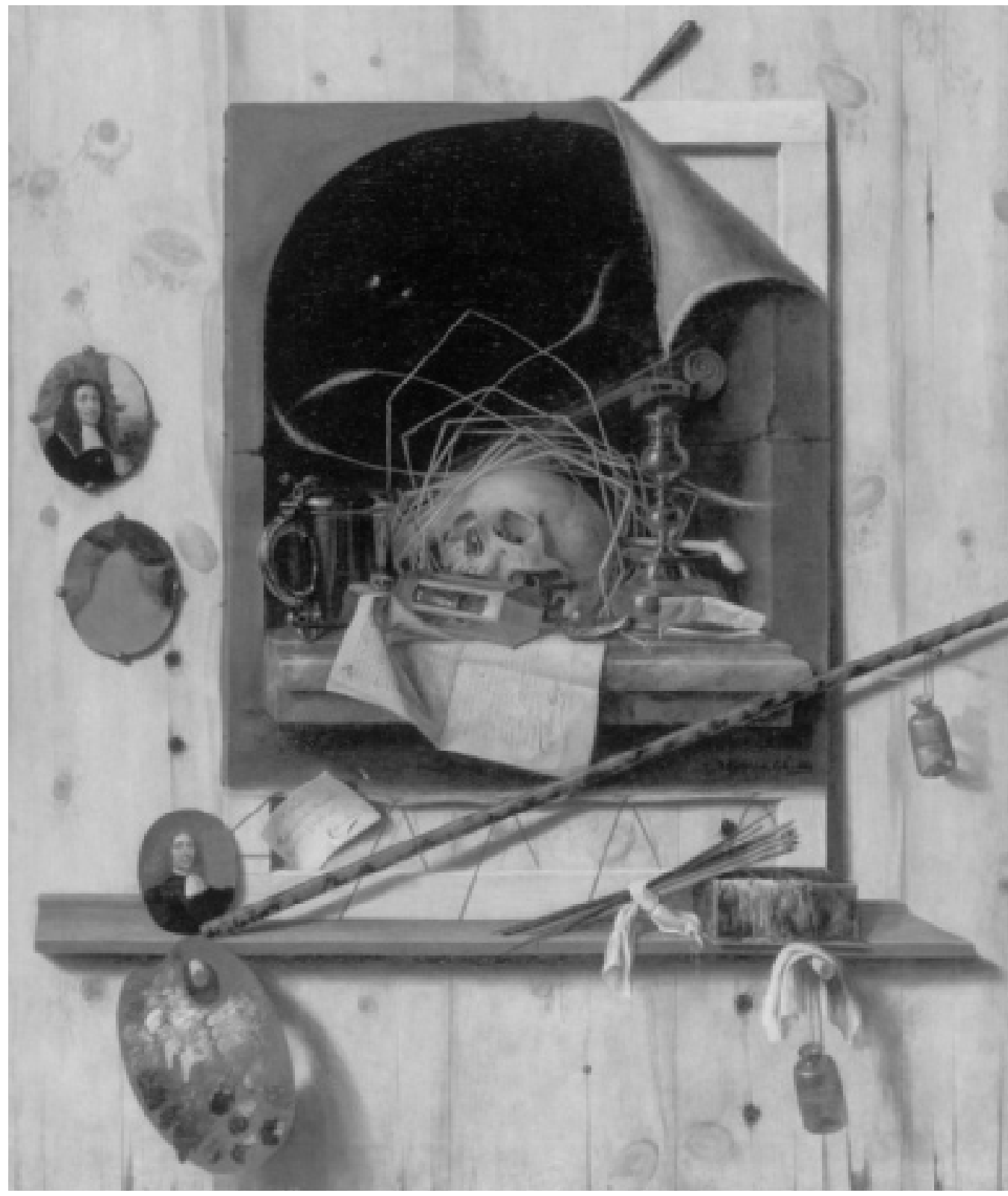

Cornelius Norbertus Gijsbrechts, 'Ateliervag og vanitas-stilleben', signeret og dateret 'C. N. Gysbrechts, F.A0. 1668'. Kobenhavn, Statens Museum for Kunst. Foto: SMK. 
Kombinationen af Cornelius Norbertus Gijsbrechts' stillebener og andre kunstneres perspektivkasser og arkitekturstykker, udført efter det geometrisk korrekte centralperspektivs regler, har da heller ikke umiddelbart nogen fællesnævner for en betragter af i dag. Man har ment, at Gijsbrechts' malerier ikke blev malet til Kunstkammeret, og at det nærmest beroede på en tilfældighed, at de havnede der (Koester 2000:17, Hein 1999:86f.).

Værkerne selv og den måde de beskrives i inventarierne taler imidlertid for det modsatte. Den store omhu og de mange ressourcer, som Frederik III og senere Christian V investerede $\mathrm{i}$ at opføre en ny bygning, peger i retningen af, at man omfattede projektet med seriøsitet, og at intet var overladt til tilfældigheder.

Gijsbrechts' maleriers tilstedeværelse i det Kongelige Kunstkammers Perspektivsal, giver anledning til at reflektere over deres funktion som rumudsmykning. Den hermeneutiske fortolkningsmodel giver mulighed for at bygge videre på den historiske forklaring og fortolkning ud fra analyser af værkernes funktion, den mentalitetshistoriske kontekst, samt malerens biografi og kunstsociologiske forhold omkring den danske konge som mæcen. ${ }^{1}$

\section{GiJsbrechts I KøbenhavN}

Statens Museum for Kunsts bestand tæller ikke færre end 19 malerier af Gijsbrechts. Malerierne forestiller såkaldte trompe l'oeiler (i.e. øjenbedragere), hvis motiver spænder lige fra bræddevægge med breve, kobberstik, malerier, jagtudstyr og musikinstrumenter til kunstkammerskabe og stilleben.

Da kun 11 af de hidtil kendte malerier er daterede, er kronologien behæftet med stor usikkerhed. De to tidligste af dem er 'Trompe l'oeil. Brevvæg med kamfoder og nodehæfte', signeret og dateret 'C. N. Gysbrechts. F. A0 1668 ' og 'Trompe l'oeil med ateliervæg og vanitas-stilleben', som er signeret og dateret 'C. N. Gysbrechts, F.A0. 1668' (Koester 1999: 158, kat.nr.9, 154, kat.nr.8). Ud over signaturen bærer sidstnævnte maleri kunstnerens mærke i form af en seddel adresseret 'A Monsuer / Monsuer Cornelius Norbertus / Gijsbrechts Conterfeÿer ggl. In. / Coppenhagen' og et lille ovalt selvportræt ved siden af seddelen. Maleriet viser en bræddevæg med et lærred opspændt på en midlertidig arbejdsblændramme, som hviler på en hylde med malerens redskaber. Det opspændte lærred er et vanitasstilleben med et dødningehoved omvundet med aks, et sandur, et brev og en del andre genstande opstillet i en stenniche. Sedlen, som er indstukket ved blændrammens nederste kant, beretter til forskel fra alle andre kendte sedler i Gijsbrechts' københavnermalerier ikke noget om, at han var kongelig maler.

Fraværet af oplysningen kunne lede til den tanke, at Gijsbrechts endnu ikke var tilknyttet hoffet på det tidspunkt maleriet blev til. Om det forholder sig sådan, ved vi ikke. Det hænger sammen med, at den vigtigste kilde til kortlægningen af kongens udgifter, kammerregnskaberne, kun er bevaret fra og med Christian Vs tronbestigelse 9. februar 1670.

Kammerregnskaberne dokumenterer en minimumperiode for Gijsbrechts' tid som hofmaler i København fra den 19. marts 1670 til den 26. marts 1672. De fem bevarede indførsler af udgifter til Gijsbrechts' malerier lyder:

- 19/3 1670: 'dend brabandske maller 350 r';

- $16 / 51670$ og 6/6 s.å.: 'den brabandske maler for hans regnskab 570 r'; 
EVA DE LA Fuente

72 • 4/2 1671 - 15/5: 'den brabanske maler for 2 skillerier 600 r';

- 4/10 1671: 'Giesbech conterfeir for 2de skillerier paa Rosenborg 60 r.' og

-26/3 1672: 'Gisbrecht brabanske maler for 7 stycker i hafven 220 r' (Marquard 1918:56, 58, 68, 76 og 85).

Vi må altså konstatere, at der ikke er bevaret nogen skriftlige kilder, der med sikkerhed fortæller, at Gijsbrechts allerede var ansat under Frederik III. Men vi har en formodning herom, da et segl med Frederik IIIs portræt ses i ovennævnte maleri 'Trompe l'oeil. Brevvæg

med kamfoder og nodehæfte', signeret og dateret 'C. N. Gysbrechts. F. A0 1668'.

Det er ikke meget, man ved om Gijsbrechts' liv og virke. At han var flamsk, kan man aflede af benævnelsen 'dend brabandske maler' og 'Gisbrecht brabanske maler'. Det rimer sandsynligvis med, at en Gijsbrechts blev optaget som mester i Skt. Lukasgildet, dvs. malerlauget, i Antwerpen i 1659/60 og at samme Gijsbrechts den 16. november 1659 blev medlem af 'Solidaliteit der bejaerde jongmans', et broderskab af ungkarle, hvis medlemmer forpligtede sig på at være hinandens sociale sikkerhedsnet i tilfælde af syg-

Cornelius Norbertus Gijsbrechts, 'Trompe l'oeil med trompet, himmelglobus og Frederik IIIs proklamation', 1670. Statens Museum for Kunst. Foto: SMK.

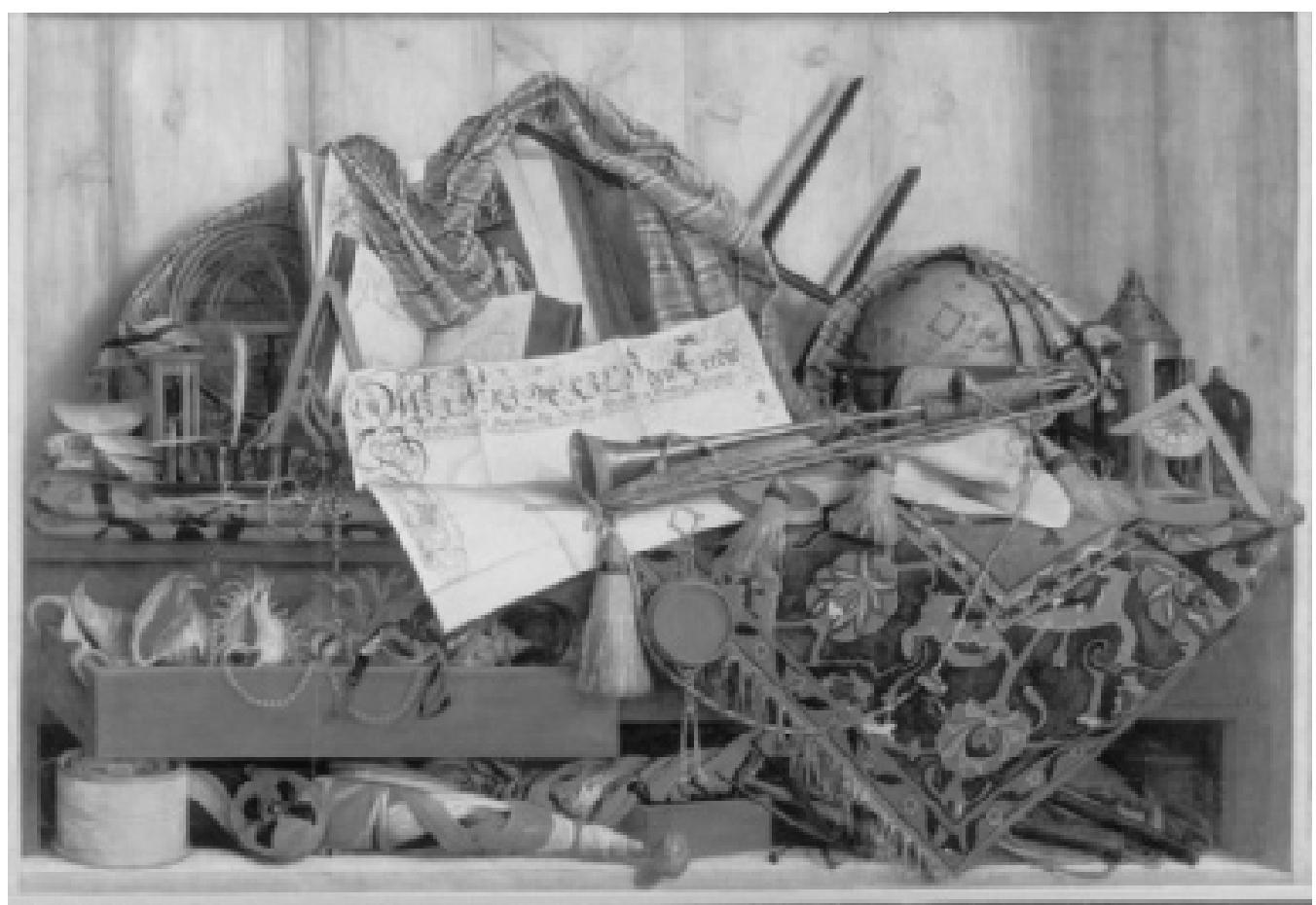


dom eller arbejdsudygtighed. (Koester 1999: 16f.).

Gijsbrechts synes kort tid efter at have søgt væk fra hjembyen og lavets beskyttende tryghed. Som omrejsende kunstner, bejlede han til konger og fyrsters gunst. Den danske konge blev hans livs vigtigste mæcen. Fra en fransk adelsmands rejsedagbog hører man, at Gijsbrechts var i Regensburg i 1664. Efter opholdet i København virkede Gijsbrechts en tid i Stockholm og i 1675 skulle han ifølge en seddel på et af hans malerier befinde sig i Breslau i Tyskland.

To af overkammerjunkerens udskrivninger til betaling af Gijsbrechts er uspecificerede, mens de resterende tilsammen nævner $11 \mathrm{ma}$ lerier. To af dem kom på Rosenborg, men hvilke er det helt umuligt at sige noget sikkert om. Syv fandtes i 'hafven', hvilket kan hentyde til et af de mange lysthuse, som var i Kongens Have (Liisberg 1914:148). Her nævnes bl.a. 'Det blå lysthus' med 'det hollandske køkken', en særlig type selskabslokale, hvor der formentlig har været en serie stillebener over et panel af hollandske kakler.

Der er med andre ord ikke noget, der taler imod at nogle af Gijsbrechts' københavnermalerier blev malet til Kunstkammeret, hvis nye bygning var under opførelse i de år Gijsbrechts var i København.

\section{HISTORISK SET}

1600-tallets kunstkamre var ofte organiseret i overensstemmelse med de principper, som pionererne i 1500-tallet havde etableret i Centraleuropa. De fleste samlere tilstræbte en universel samling, en koncis version af hele verden, som et mikrokosmos, der stod for summen af makrokosmos (MacGregor 1994:

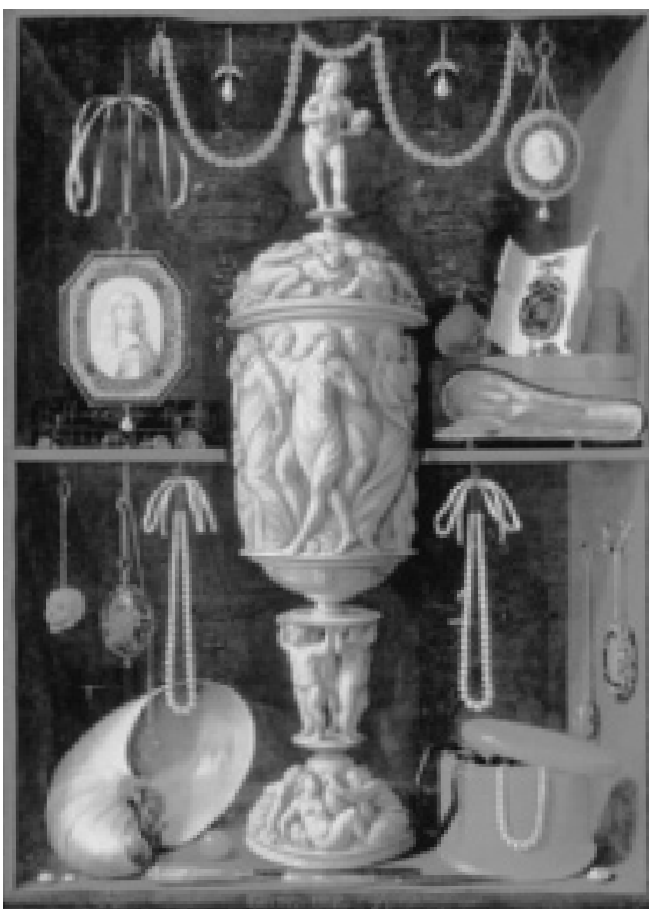

Georg Hinz: Kunstkammerskab med elfenbenspokal, 1665-67. Statens Museum for Kunst. Foto: SMK.

61ff.). Mange universalkunstkamre var delt op i tre hovedafsnit: 'Artificialia' - genstande tilvirket af mennesker ved kunstfærdighed og snilde, 'Naturalia' - eksemplarer skabt af naturen, 'Antiquitates' - gamle genstande.

Johan David Köhler, professor ved Göttingens Akademi, giver $\mathrm{i}$ en rejseguide udgivet posthumt i 1762 en indføring i forskellige typer samlingers opbygning og særkende. Kunstkamrene beskrives som samlinger bestående af genstande fra naturens og kunstens riger med følgende præcisering: "Et rigtigt kunstkammer er egentlig en samling af ting, som mennesker har frembragt ved forbløffende flid og 


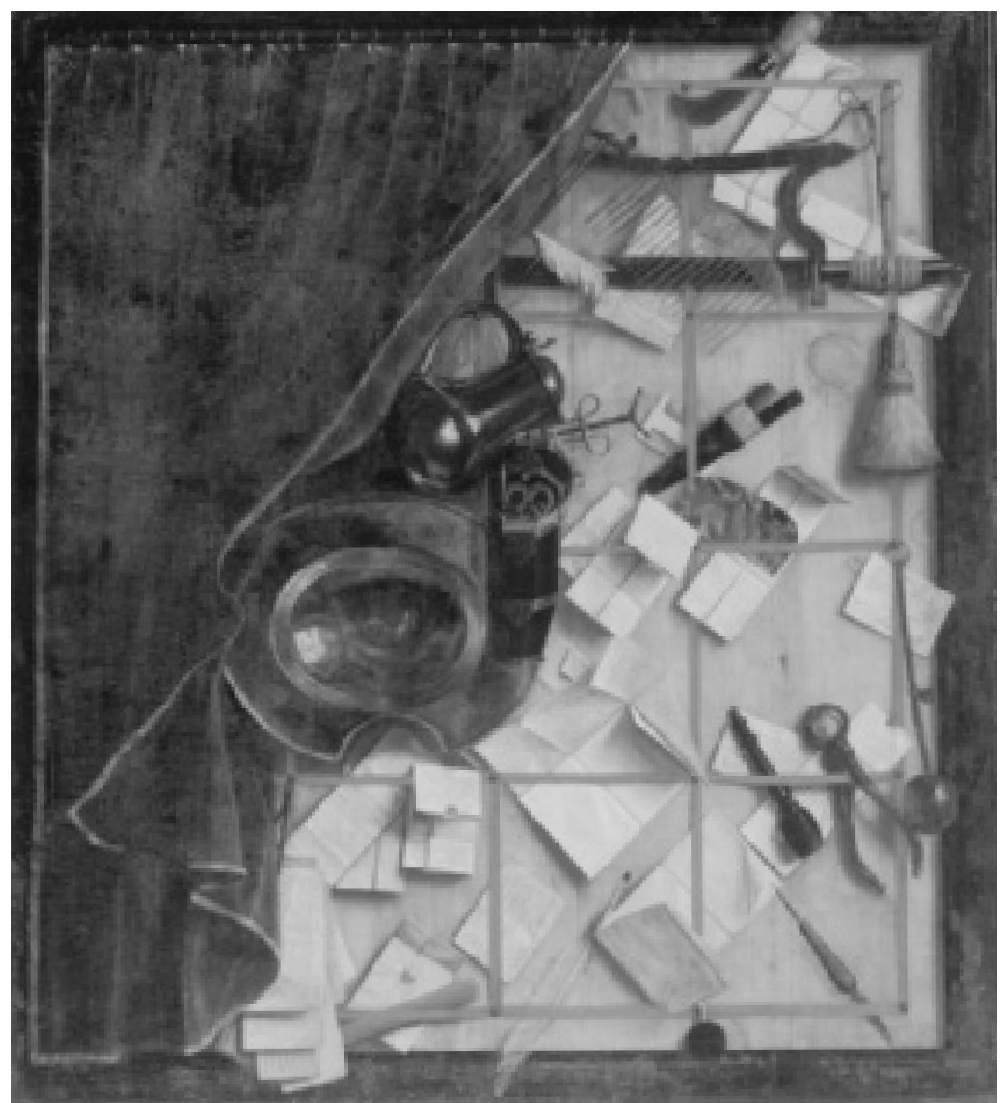

Cornelius Norbertus Gijsbrechts, 'Brevvag med bartskar-instrumenter'. U.a. Statens Museum for Kunst. Foto: SMK.

naturefterligning. Kunsten og naturen skal derfor selvsagt holdes specielt adskilte". ${ }^{2}$

I forhold til andre europæiske universalkunstkamre er Det danske kongelige Kunstkammer en sen udgave. Dets historie tegner først sine tydelige konturer med Frederik IIIs tronbestigelse i 1648. Forinden havde Christian IV indrettet et kunstkammer med sjældne og kostbare våben på sit lystslot, Sparepenge ved Frederiksborg Slot i Hillerød (Hein 1998:122). Men et egentligt universalkunstkammer fik Christian IV aldrig etableret.
Det gjorde Frederik III derimod. Som statholder i hertugdømmerne Slesvig-Holsten havde han anlagt en samling kunstkammersager med forbillede i sin navnebror og fætter, Frederik III af Gottorps samling (1597-1659). At Johan Köhler i sin rejseguide priser den gottorpske fyrstes kunstkammer som en af de tre mest berømte, taler for sig selv (Köhler 1762:257).

Efter kroningen i 1648 indrettede Frederik III kunstkammersamlingen i tilknytning til Drejerkammeret i sin nye residens på Køben- 
havns Slot. I 1653 blev otte nye rum indrettet i slottets sydfløj. Samlingen blev forøget betydeligt med tilgangen af lægen og oldforskeren Ole Worms samling efter dennes død i 1654.

Kunstkammerets enorme ophobning af ting får man et indtryk af gennem inventariet fra 1674, det eneste, der er bevaret fra Kunstkammerets tid på Københavns Slot.

Rummene var 'Det første Gemach' med naturalia, 'Det andet Gemach' med Artificialia, 'Gewehr Gemacket' med våben og antikviteter, 'Schilderi Gemachet', 'Det Mathematische Kammer' med videnskabelige instrumenter, ure, optiske apparater og en del anamorfoser eller cylinderperspektiver, hvoraf kun én er bevaret i dag, nemlig Nationalmuseets bordanamorfose med et dobbeltportræt af Frederik III og Dronning Sofie Amalie. Herefter kom 'Det Ost-Indiske Camers' med etnografika, ' Medallie Cabinettet' og til sidst 'Forstuen' med Albert Eckhouts malerier med brasilianske motiver (Gundestrup 2004) og 'Model Kammeret' med arkitekturmodeller af kongernes opførte så vel som ikke opførte byggeprojekter.

Indretningen af Kunstkammeret i den nye bygning tog først fart under Christian V. Mere end et tiår efter Frederik IIIs død kan vi i kammerregnskaberne læse den første udskrivning til dækning af udgifter til indretningen. Den 29. december 1681 noteres: 'Bendix kunstdreier til et kamers at lade ferdiggiøre paa kunstkamerset 32r 4m' (Marquard 1918:253). Herefter noterer overkammerjunkeren den ene udskrivning efter den anden til Kunstkammerets forvalter Bendix Grodttschilling. De største poster til indretning af rummene forekommer i årene 1682 til 1685. ${ }^{3}$

Perspectiv Kammeret har senest været færdigindrettet 1689-90 med de første inventariers udarbejdelse. Man må formode, at Frede- rik III og Christian V samt deres rådgivere havde en plan for det nye Kunstkammers indretning allerede ved byggeprojektets start. En plan, som i så fald forelå, da Gijsbrechts blev indkaldt som hofmaler. At udskrivningerne til indretningen af Kunstkammeret først sætter ind i starten af 1680'erne kan skyldes den skånske krig 1675-79, og at Christian V havde mange bekostelige initiativer i gang, bl.a. en modernisering af Rosenborg og opbygningen af en samling pretiosa og nye kronjuveler (Hein 1994:326, Hein 1998:123). Initiativer, der ligesom opførelsen af biblioteksbygningen, skulle kaste glans over den unge enevælde.

\section{KunStKammerideEN OG GIJSBRECHTS' MALERIER}

Flere af Gijsbrechts' københavnermalerier indeholder referencer til de genstande, som man almindeligvis kunne forvente at finde $\mathrm{i}$ et kunstkammer, nogle af genstandene i Cornelis Gijsbrechts' malerier er ligefrem 'portrætter' af genstande i kongens samlinger, men ikke nødvendigvis genstande, der befandt sig $\mathrm{i}$ Kunstkammeret.

At mange af Gijsbrechts' malerier kan siges at handle generelt om kunstkammeret som verdensteater og specifikt om det københavnske Kunstkammer er i sig selv tungtvejende argumenter for, at malerierne var bestilt hertil. Perspectiv Kammeret var en nyskabelse i forhold til Kunstkammerets tid på Københavns Slot. Perspectiv Kammeret som specifik rumtype synes tillige at være enestående for det københavnske Kunstkammer.

Det mest oplagte eksempel på en forbindelse mellem motiv og kunstkammerbegrebet, er pendanterne forestillende kunstkammer- 
skabe, det ene med en malet åben låge, det andet med en rigtig låge, der kan åbnes. (Koester 1999:162, kat.nr.11, 164, kat.nr.12). Kunstkammeret som idé er også tema for 'Trompe l'oeil med trompet, himmelglobus og Frederik III's proklamation' og pendanten 'Trompe l'oeil. Malerier, malerredskaber og et blomstertæppe i kunstnerens atelier' (Koester 1999:168, kat.nr.13, 172, kat.nr.14).

Det synes ikke tidligere bemærket, at de to malerier forestiller et kig ind i den nederste del af et åbent skab. Den form for skabe med ringe dybde kendes fra andre kunstkamre. ${ }^{4}$ Georg Hinz specialiserede sig ligefrem i at male den slags trompe l'oeil kunstkammerskabe, som Perspektivkammeret giver et eksempel på. Trompe l'oeil effekten i Georg Hinz' illusionistiske repræsentation består i, at skabets kanter falder sammen med billedrammen på samme måde som i Gijsbrechts' pendanter.

Gijsbrechts' pendanter er ikke anonyme fremstillinger af kunstkammerideen sådan som Georg Hinz' maleri. I 'Trompe l'oeil med trompet, himmelglobus og Frederik III's proklamation' ses en sammenhobning af konkylier, koraller, en armillarsfære, en globus, et dyrekranium, måle- og navigationsinstrumenter af forskellig art. Alt sammen ting fra naturens og kunstens verden, Naturalia og Artificialia. Muligvis er nogle af konkylierne 'portrætter' af de konkylier, som var tilgået Kunstkammeret med Ole Worms samling. Kompositionen domineres af den smukt kalligraferede proklamation, der fremhæver den enevældige kongemagts position som lovgivende magt. En militærtrompet, der ligger hen over proklamationen, hentyder til kongens rolle som landets militære overhoved. Bag proklamationen er 'udstillet' et par folianter, som kunne være referencer til Frederik III som bibliofil og lærd konge. Maleriet samler Mars, Lex og Ars under ét i en hyldest til den konge, som startede opførelsen af den bygning, der skulle rumme alle tre samlinger, Tøjhusets våbensamling, Det Kongelige Bibliotek og Kunstkammeret. Maleriet er signeret og dateret 1670 og kan altså være malet både før og efter Frederik III's død.

Et hidtil overset eksempel på et maleri af Gijsbrechts, som også kan tolkes som en henvisning til Kunstkammerets mange genstandsgrupper, er 'Brevvæg med bartskær-instrumenter' datidens kirurgiske instrumenter, som bl.a. fandt anvendelse i tidens revolutionerende nye udforskninger af menneskekroppen gennem dissektioner (Koester 1999:160, kat. nr.10). I professor Johan Köhlers rejseguide fra 1762 fremhæves bl.a. den højlærde kurfyrste August af Sachsens samling af Kirurgiske instrumenter, som var udstillet i dertil indrettede skabe sammen med urmagernes, guldsmedenes, juvelerernes, drejernes og snedkernes instrumenter og værktøj (Köhler 1762: 256f.).

Johan Köhler fortæller videre, at August af Sachsen også havde en samling håndværks- og kunstnerinstrumenter. Kunstnerinstrumenter findes i flere af Gijsbrechts' københavnermalerier, pendanten til trompe l'oeil kunstkammerskabet med Frederik III's proklamation, den ovenfor omtalte bræddevæg med vanitasstilleben og ikke mindst Gijsbrechts' cutout 'Staffeliet'.

I 22 afsnit gør Johan Köhler detaljeret rede for, hvad man kan finde i et kunstkammer. Efter håndværkernes, kunstnernes og kirurgernes instrumenter nævnes:

II Modeller af berømte bygninger, kirker, paladser o.l. III Kunstfærdigt udskårne genstande i elfenben, næsehorn, strudseæg, 'Speckstein' og kokosnød; IIII kunstfærdige genstande, som konger og fyrster selv har til- 
virket. Det kan være indenfor tegne- og malerkunsten, drejerkunsten eller glasslibning for eksempel; V Håndværkeres mesterstykker; VI Musikinstrumenter, gerne gamle historiske instrumenter. Köhler nævner Athanasius Kirchers bog Musurgia, hvilket er interessant, fordi Fransiscus Gijsbrechts' maleri 'Bræddevæg med musikinstrumenter' netop viser Christian IV-tidens instrumentarium (Koester 1999: 220, kat. nr. 35).

Johan Köhler fortsætter sin opremsning, som i sig selv illustrerer renæssancens universal kunstkammer (Köhler 1762:161 ff.):

VII kunstfærdigt fruentimmerarbejde; VIII Subtil skrift, dvs. kuriøse ting dannet af skrift eller tekster skrevet med meget små bogstaver; VIIII Sager lavet af elendige og gebrækkelige mennesker, dvs. smukke malerier eller ting udført af mennesker med et eller andet handikap.

Interessant i forbindelse med Kunstkammerets Perspectiv Kammer og de optiske instrumenter og anamorfoser, som befandt sig i Det Matematische Kammer, er Johan Köhlers afnit X om 'Optiske sager'. Til den kategori hører først og fremmest 'Perspective und Tubi'. Johan Köhler gør meget ud af at beskrive de optiske instrumenter og hvem, de er opfundet af. Han nævner teleskopet, briller, 'Tubos terrestres mit vier Gläsern', 'Tubi binoculi', 'Helioscopi, die aus grünen und blauen Gläsern bestehen' og ikke mindst 'verschidene Laternas magicas, da man durch Convex-Gläser schöne Bilder präsentiret'.

Johan Köhler nævner dernæst Camera Obscura og de trekantede glas 'Prismata', som meget smukt forklarer farvernes oprindelse. Man viser også 'polyedra, die auf einer Seite platt, und auf der andern vieleckigt sind' og spejle, konvekse, konkave, cylindriske og koniske'. Alt sammen ting, der var i Det køben- havnske Kunstkammer eller i Det grønne Kabinet på Rosenborg. Köhlers udførlige gennemgang af optikkens genstandsfelt og dets rige repræsentation i det københavnske Kunstkammer illustrerer tidens store interesse for optikken og de dermed forbundne videnskaber som perspektivkunsten og matematikken. Etableringen af Perspectiv Kammeret lå i forlængelse af den interesse.

Mentalitetshistorien har set trompe l'oeilen, illusionismen, metaforen og allegorien som

Cornelius Norbertus Gijsbrechts, 'Trompe l'oeil-staffeli med frugtstykke'. U.å. Statens Museum for Kunst. Foto: SMK.

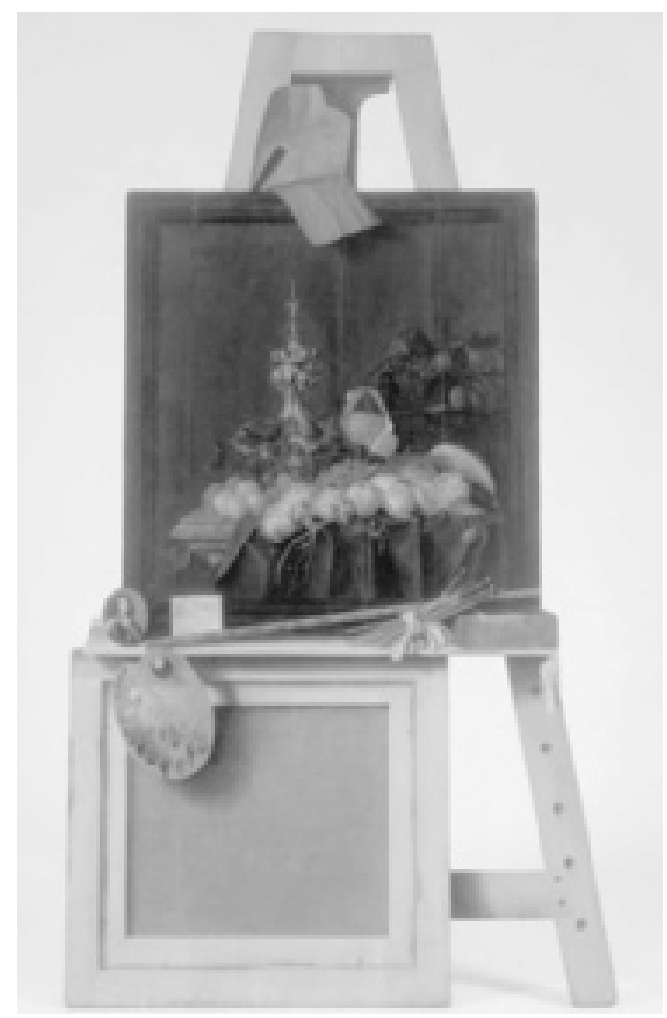


78 det, der definerer barokken i forhold til den foregående epokes søgen og navigeren efter ligheder (Foucault 1997:51). Renæssancens ophøjede, strenge og restriktive mimesisideal og søgen efter ligheder mellem tingene afløses af barokkens trompe l'oeil og vittige illusionisme, hvor maleriet bliver til et metamaleri, der fremstiller sig selv i en spøgefuld leg med billedbegrebet. Og hvor maleren refererer til sig selv og sin metier i et net af 'visitkort'.

Gijsbrechts' malerier kan siges at have en fod i begge lejre. Maleriernes referencer til kunstkammerbegrebet afspejler renæssancens søgen efter ligheder. Det er et princip, som i nogle tilfælde kan være styrende for maleriers placering rundt om i Kunstkammeret (jfr. Britta Tøndborgs artikel). Hos Gijsbrechts blandes renæssancens tænken i analogier med barokkens smag for trompe l'oeilens leg med sanserne, cylinderperspektivets hokus pokus og camera obscuraens forvandling af verden.

\section{INVENTARIET 1674}

Inventariet blev udarbejdet $\mathrm{i}$ forbindelse med kongelig 'Bibliothecario' Willum Worms udnævnelse til overinspektør ved Kunstkamme-

Cornelius Norbertus Gijsbrechts, 'Trompe l'oeil med måltidsstykke med pragtkar' 1672.

Statens Museum for Kunst. Foto: SMK.

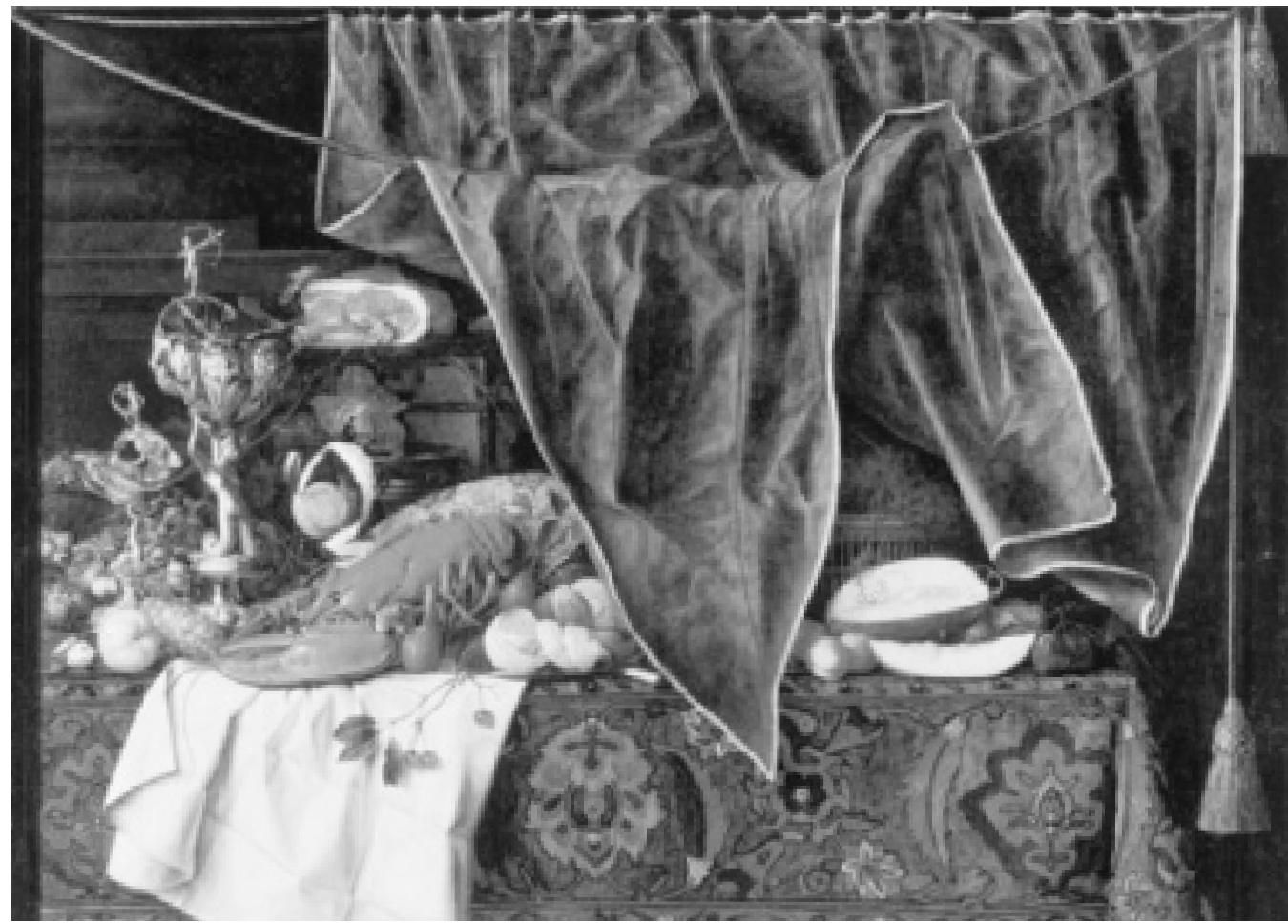


ret på Københavns Slot. Malerierne var for størstedelens vedkommende samlet i Schilderi Gemacket. Blandt dem er 'Staffeliet' identificeret som det eneste værk af Gijsbrechts (Gammelbo 1956:148, kat.nr.23, Gundetrup 1991-95, II: 896/12 29-30). Mellem portrætter af kendte personligheder, landskaber og mytologiske motiver er det indført med følgende beskrivelse: 'En frugtstøche med Contrafejers instrumenter maalit paa Perspectiv' (Inventarium 1674:26a).

Umiddelbart inden staffeliet nævnes 'Toe Kamfoore maalet paa Perspectisk'. Så vidt vides er det ikke tidligere blevet bemærket, at de kan identificeres med to chantournéer eller 'cutouts' svarende til staffeliet, blot forestillende kamhylstre af tekstil til opbevaring af personlige ting (gengivet i Jongh 1982:147, nr.1). Da Kunstkammeret blev opløst i 1824, blev de solgt under auktionskatalogets nr. 559: 'Adskillige bedærvede Kunstsager..' til en Kanc. Bang (Bente Gundestrup takkes for oplysningen). Poul Gammelbo katalogiserer dem i Kunstmuseets Aarsskrift 1952-55 som værende på Gavnø Slot 1914 (Gammelbo:150, kat.nr.29). Hos Jongh 1982 oplyses de at være i en nederlandsk privatsamling. De kan sandsynligvis dateres til 1671, årstallet på en almanak fra Haarlem, som er stukket ind i en lomme på det ene kamhylster. En billet foroven i det andet kamfoder identificerer ophavsmanden: 'A Monsieur / Monsi Gysbrechts Kon / terfyer von Ihr Koni . / ...may von Dennema / Co.. ggl. '

Et fjerde værk i Schilderi Gemacket beskrives som 'Et støche med en Hummer paa', hvilket sandsynligvis refererer til Gijsbrechts' morgenmad-stilleben, hvor en stor hummer på et porcelænsfad dominerer. ${ }^{5} \mathrm{Vi}$ kan altså konkludere, at det ikke kun var 'Staffeliet', som fandt vej til Kunstkammeret på Køben-

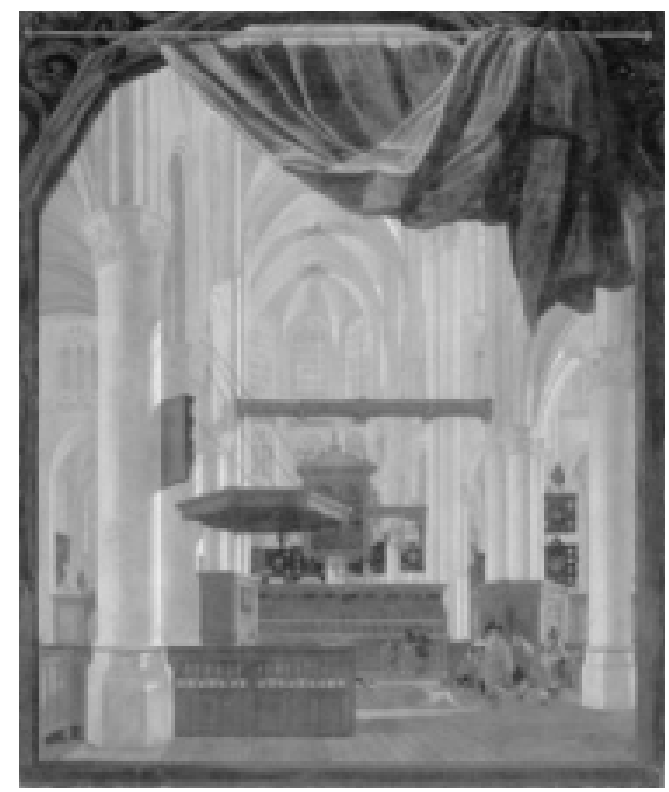

Gerard Houckgeest, 'Det indre af Sint Gertrudiskerk i Bergen Op Zoom'. 1655.

Statens Museum for Kunst. Foto: SMK.

havns Slot, men at der var to måske tre andre værker af Gijsbrechts i Schilderi Gemacket.

\section{Det oprindelige Perspectiv Kammer}

Det upublicerede inventarium fra 1690 er særligt interessant, fordi det giver den tidligste beskrivelse af Christian V's Kunstkammer efter indretningen i den nye biblioteksbygning. Det giver med andre ord et klart indtryk af Perspektivkammerets oprindelige sammensætning. Inventariet fra 1737 vidner om, at man satte ting på Kunstkammeret i en lind strøm. For eksempel er der allerede i 1737 kommet en del portrætter og genrebilleder ind i Perspectiv Kammeret og senere bragte en stor 
80 samling udstoppede trækfugle fanget ved Bornholm den oprindelige intention endnu mere ud af fokus (Journal 1771:1).

Inventariet fra 1690 blev udfærdiget af Willum Worm og bisidderne Poul Vinding og Holger Jacobæus i forbindelse med Bendix Grodtschillings overtagelse af hvervet som forvalter efter sin fader af samme navn. Ligesom Kunstkammeret på Københavns Slot havde været det, blev det nye Kunstkammer ordnet efter den norm, som renæssancen etablerede med tredelingen mellem Naturalia, Artificialia og Antiquitates. Hertil kommer det nye Kunstkammers Perspectiv Kammer, som er den eneste reelle nyskabelse $\mathrm{i}$ forhold til Kunstkammeret på Københavns Slot. Hvad var det så, der mødte den besøgende i Perspectiv Kammeret, på dørtrinnet til Det kongelige Kunstkammer. ${ }^{6}$

1. Én Catholisk kjerche udj perspectiv

2. Én reformerit kjerche udj perspectiv.

3. Et stort Optiske Styche staaendis paa et postement, gjort af én fornemme Mester Fabricio Delft.

4. Et perspectiv med én Dame og én Cavallier udj et Gemach.

5. Et dito med et langt Gallerje udj.

6. Dend Harlemske kjerche perspectiv-wiis skildret af én fornemme Mester.

7. Tolf kunstige stycher med adskillige figurer paa af Cornelio Gübsbrecht.

8. Siuf skilderier med adskillige Diur, Fugle och andet paa meget kunstige.

9. Toe Frugt-stycher, et stort og et lidet, meget kunstige.

10. Et styche med frugter paa og hvad instrumenter som hør til én skildrer.

11. Et skilderje med et stort Elphenbeens pocal og adskillige andre curiositeter udj et skab med glas for, gjort af Georgio Hindz.

12. Tvende kamfoere meget vel skildret.
I et appendix er følgende tilføjelser:

1694.

Et Skilderie, hvorpaa en AggerHønne og allehaande andre Sager.

1696.

Et skønt Skilderie, hvorpaa Pont Neuf til Paris, giordt af Waverman.

En Catholisk Kirkes Skilderie paa én Kaaber-Plade.

Gijsbrechts' malerier nævnes altså uspecificeret under pkt. 7 som 'Tolf kunstige stycker' i betydningen kløgtigt eller dygtigt udførte malerier. Gijsbrechts' tre 'cutouts', staffeliet og de to kamhylstre, nævnes under pkt. 10 og 12 uden angivelse af ophavsmanden. Inventariet fra 1737 identificerer heller ikke værkerne nærmere. Her lyder teksten 'Atten kunstige Malerier af diverse størelse med adskillige figurer i Stillleben, malet af Cornelius Gisbrecht'.

I inventariet fra 1690, er under pkt 1-5 det, der gennem det originale tysksprogede inventarium fra 1690 kan identificeres som perspektivkasser.

1. Einen Kasten, worinnen eine Romisch Catholische Kirche nach Perspectivischer Kunst gemahlet.

2. Einen Kasten, worinnen gleicherweise eine Reformirte Kirche gemahlet.

3. Einen Kasten, worinnen eine grosze optische Perspective.

4. Einen Kasten, worinnen eine hollandsche Vorstube.

5. Ein dito mit einer langen Gallerej.

Perspektivkasserne beskrevet under 1, 2 og 4 er endnu bevaret på Nationalmuseet. De to første er af kunsthistorikeren Walter A. Liedtke tilskrevet Hendrick van Vliet (Liedttke 1976: 131f., Brown 1981: 135, R17). I tråd 
med Gijsbrechts' malerier er den ene kasse udvendigt malet som et trompe l'oeil skab med mønter og en koralperlekæde i de halvt åbne skuffer. Den tredje perspektivkasse er et værk af 'én fornemme Mester Fabricio Delft', alias Carel Fabritius, af hvem kun ganske få værker er bevaret (Brown 1981). Carel Fabritius' perspektivkasse blev solgt på auktion i forbindelse med Kunstkammerets opløsning i 1824 sammen med mange andre af de mest kuriøse genstande. Af Kunstkammerets inventarium fra 1737 ved vi, at den havde et ikke nærmere specificeret motiv 'med Architectur' (Gundestrup 1991-95, II, 416). At det store 'Optiske Styche' stod på et postament, tyder på, at Carel Fabritius' perspektivkasse har været af samme type, som Samuel van Hoogstratens perspektivkasse på National Gallery i London (Gengivet i Brusati 1995, plate IV og V).

Med 1690-inventariets pkt. 6, Dend Harlemske kjerche perspectiv-wiis skildret af én fornemme Mester' begyndes gennemgangen af malerier i Perspectiv Kammeret. I inventariet fra 1737 beskrives værket som 'Et Maleri forestillende den Harlemske Domkircke paa perspektivisk maade meget herlig malet af Georg Hintz'. Maleriet er blevet identificeret med et af Statens Museum for Kunsts bedste arkitekturmalerier, et interiør som har vist sig at være fra Skt. Gertrud Kirke ved Bergen Op Zoom (Gundestrup 1991-95:II:418). Når kunstkammerinventariet nævner Georg Hinz som ophavsmand, er det på grund af monogrammet $\mathrm{GH}$, som i dag regnes for at være Gerard Houckgeests ubetvivlelige signatur. Interiøret er udført i et geometrisk korrekt perspektiv, hvilket gør tilstedeværelsen i Perspectiv Kammeret naturlig. Houckgeest har med en illusionistisk malet ramme og et malet forhæng desuden indskrevet sit kirkeinteriør i trompe l'oeil traditionen.

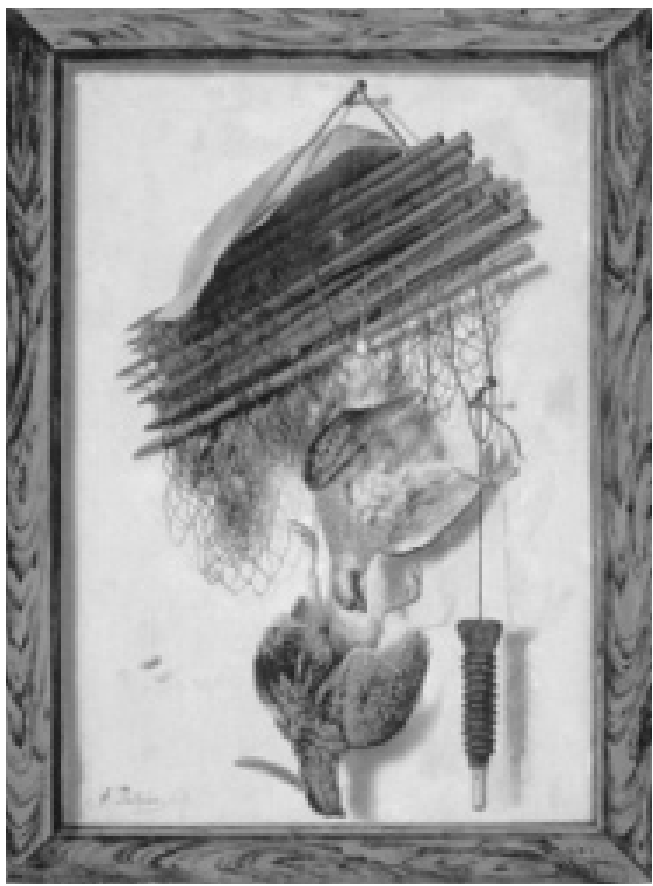

Jacob Biltius, 'Trompe l'oeil. Indrammet billede med dodt fuglevildt og fuglenet ophangt på en mur. 1679. Statens Museum for Kunst. Foto: SMK.

Fire af de under 1690-inventariets pkt. 8 nævnte stillebener med dyr og fugle, kan ved hjælp af inventariet fra 1737 identificeres med værker af Jacob Biltius, som i dag indgår i Statens Museums bestand. ${ }^{7}$ Det, der kvalificerer Jacob Biltius' malerier til Perspectiv Kammeret, er deres trompe l'oeil effekter som for eksempel en malet ramme i stedet for en virkelig ramme eller slagskygger, der får tingene til at se virkelige ud.

1690-inventarets katalogisering af to frugtstilleben, et stort og et lille, er i 1737-inventaret blevet til 'Et liidet Frugtstycke proper ma- 
82 let af Johan de Heime', hvorved det kan identificeres som museets bevarede stilleben af Jan Davidsz de Heem. Næste indførsel kan takket være 1737-inventariet identificeres med Gijsbrechts' chantournée-maleri, staffeliet, ved følgende ordlyd: 'Et stycke paa udskaaren Træ, med Frugter og nogle til Maleriet hørende Sager, malet af bemelte Cornelius Gisbrecht'.

Det under pkt. 11 nævnte maleri med en elfenbenspokal og 'adskillige andre curiositeter udj et skab med glas for', er i 1737-inventariet beskrevet som 'Et Maleri i fouteral, hvorpaa én stor Elfenbeens pocal og adskillige andre sager malet af Georg Hintz'. Det kan med sikkerhed identificeres som Statens $\mathrm{Mu}$ seum for Kunsts maleri af den tyske maler Georg Hintz, som også arbejdede for Frederik III's fætter og navnebror, Frederik III af Gottorp. Med sit opbud af bemærkelsesværdige og kostbare ting fra naturens såvel som kunstens rige, er Hintzs maleri en reference til kunstkammeret som sådan. På Rosenborg var man netop i færd med at indrette Det grønne Kabinet med pokaler og pretiosa på præcis den måde (Hein 1994:323ff.).

Tilføjelserne i 1694 og 1696 af et uidentificeret dyrestykke, et ditto kirkeinteriør og Pieter Wouwermans store panorama af Pont Neuf i Paris ligger inden for Perspectiv Kammerets oprindelige idé.

\section{Kunsten og Naturen}

Med sine trompe l'oeiler og perspektivstykker repræsenterer Perspectiv Kammeret et af barokkens helt store topoi: Den fra antikken nedarvede kappestrid mellem naturen og kunsten. Kan Apelles og hans efterkommere med deres pensler, farver og avancerede perspektiv konstruktioner nogensinde komme på højde

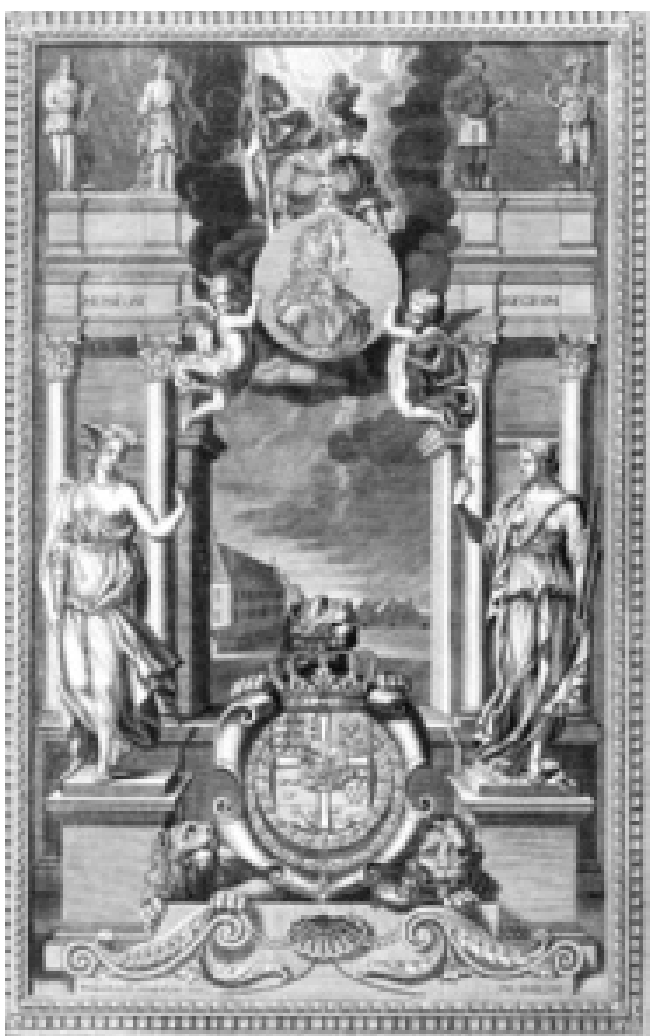

Kobberstukkent titelblad til 'Museum Regium' af Holger Jacobaus. København 1696. Danmarks Natur-og Lagevidenskabelige Bibliotek. Foto: Bent Grøndahl.

med de vidunderlige forekomster, som Moder Natur selv frembringer uden menneskets indvirken? Med andre ord: Kan maleren male, så betragteren snydes til at tro sig overfor virkelige ting? (Heinrich 1996:19f.)

At den danske konge og hans rådgivere var bevidste om dette topos fremgår af titelbladet til Museum Regium, det pragtværk om Kunstkammeret, som Christian V udgav i 1696. Titelkobberet refererer både til den enevældige 
monark og til Kunstkammerets essentielle idé om naturens og kunstens kappestrid. Foran en triumfbue i den korinthiske søjleorden ses øverst et rundt portræt af Christian V fremholdt af Pallas Athene, kunstens beskytter, og svævende putti. Til venstre herfor står en statue af Filosofien (?) med en statuette af den græske gudinde Artemis som Moder Natur, og til højre Maleriets kvindelige personifikation med palet, malestok og måleinstrumenter. På triumfbuens gesims står fire kvindelige personifikationer af kontinenterne, som lig Filosofien, Naturen og Kunstens personifikationer hentyder til Kunstkammerets betydning som et mikrokosmos, der favner hele verden. Gennem triumfbuens midterfelt ses den nye biblioteks- og kunstkammerbygning i det fjerne. På et postament foran triumfbuen holder tre løver rigsvåbnet omvundet med elefantordenen og kronet af den nye enevoldskongekrone.

\section{SLUTREPLIK}

Cornelius Norbertus Gijsbrechts var repræsenteret med mindst tre værker i Kunstkammeret, mens han endnu virkede i Danmark som kongelig hofmaler. De tre 'cutouts' af et staffeli og to kamhylstre blev inden 1689-90 suppleret med 12 malerier, som tilsammen udgjorde topnummeret i Kunstkammerets forgemak i den nyopførte biblioteksbygning. Ingen skriftlige kilder taler imod en formodning om, at Gijsbrechts' malerier fra tilblivelsestidspunktet var tiltænkt den nøgleposition.

Perspectiv Kammeret var et kostbart skuestykke, som skulle imponere og overraske den besøgende med en kunst, der var helt ny og skelsættende for sin tid. De øvrige kunstværker - perspektivkasser, arkitekturstykker og trompe l'oeil-stilleben af kunstnere som Carel Fabritius, Georg Hinz og Jacob Biltius - var også eksponenter for barokkens søgen efter illusionen og det vittige synsbedrag. Rumudsmykningens funktion var at åbne Kunstkammeret med et illusionsnummer, der skulle slå benene væk under enhver, og kaste glans over enevælden.

Perspectiv Kammerets fællesnævner er trompe l'oeilen. Et mere tidstypisk topos findes næsten ikke. Mentalitetshistorien har set trompe l'oeilen som et af barokkens mest typiske fænomener på linie med allegorien og metaforen. Samtidig peger Gijsbrechts' malerier bagud. Deres kredsen om kunstkammeret som motiv afslører renæssance-kunstkammerets søgen efter ligheder: Malerierne i Kunstkammerets indgangsrum skal handle om kunstkammeret som begreb.

Perspectiv Kammerets funktion var også at kaste glans over den nyligt indstiftede enevælde og vise monarkens ansigt $\mathrm{i}$ bogstavelig og overført forstand. Perspectiv Kammeret er båret af en idé, der handler om at bedrage og fornøje øjet med et maleri, der legende refererer til sig selv, sin ophavsmand og hans kongelige mæcen.

\section{NOTER}

1. Om den hermeneutiske fortolkningspraksis, se Bätschmann 1996, p.192-222.

2. Egen oversættelse, Köhler 1762, p.256, 'Eine rechte Kunst-Kammer ist eigentlich eine Sammlung von Dingen, die der Mensch durch erstaunenden Fleiss und Nachahmung der Natur hervorgebracht hat. Es müssen Dinge seyn, die einen grossen Verstand und erstaunenden Fleiss anzeigen. Die Kunst und die Natur müssen daselbst besonders von einander unterschieden werden.' 
3. Der bliver foretaget snedkerarbejde og andet mere eller mindre uspecificeret indretnings- og vedligeholdelsesarbejde på kunstkammeret helt frem til 1697, to år før Christian V's død. Marquard 1918: 253, 255, 257, 269, 283, 303, 317, 332, 334, 339, 346, 357, 372, 440, 466, og 491.

4. MacGregor 1994:2, 71, fig.5 viser eksempler fra titelbladet til C.F. Neicklius 'Museographia' fra 1727 og Albrecht V's kunstkammer i Schloss Ambras ved Insbruck.

5. Der kan ikke være tale om Frans Snyders store stilleben med en hummer (inv.nr. KMSsp208), da det blev erhvervet i 1755. Det eneste andet bevarede maleri fra de kongelige samlinger med en hummer er kopien efter Snyders (inv.nr. KMSst219), som er registreret i Stroes katalog fra 1648.

5. Inventarium 1690:349. Til det følgende er det originale tyske inventarium, som findes i afskrift på Statens Museum for Kunst, blevet anvendt sammen med en kopi af det danske inventarium på Nationalmuseet. Begge disse er suppleret med en ordret transkription ved John Bundgaard Rasmussen 1985, som Bente Gundestrup takkes for at have tilvejebragt.

7. Gundestrup 1991-95, II:428ff., 896/34,896/35, 896/36 og 897/37, KMSsp608, KMS3029, KMSst576 og KMSsp609.

\section{LITTERATUR}

Bencard, Mogens: "Cornelis Gijsbrechts Trompe l'oeil". Musikkens tjenere. Instrument. Forsker. Musiker. Meddelelser fra Musikhistorisk Museum og Carl Claudius' Samling VI. København 1998, pp. 167-174.

Bencard, Mogens, Jørgen Hein, Bente Gundestrup og Jan Drees: Die Gottorfer Kunstkammer. Gottorf im Glanz des Barock II, Schleswig 1997.

Bjerre, Henrik (ed.): Restaureringsbilleder. En udstil- ling om bevaring og undersøgelse af ældre kunst. Udst.katalog. with english text. København 1984. Braun, Michael: Trompe-l'oeil - Ehre und Ansehen durch Betrug. Im Blickfeld. Georg Hinz. Das Kunstkammerregal. Udstillingskatalog, red. Christoph Heinrich. Hamburg 1996, pp. 35-41. Brown, C.: Carel Fabritius. Oxford 1981.

Brusati, Celeste: "Stilled Lives: selfportraiture and self-reflection in seventeenth-century Netherlandish still-life painting". Simiolus, vol. 20, nr. 2/3, 1990-91, pp. 168-182.

Brusati, Celeste: Artifice and Illusion. The Art and Writing of Samuel van Hoogstraten. Chicago og London 1995.

Brusati, Celeste: "Ærlige bedragerier og tvivlsomme distinktioner: Selviscenesættelse i trompe l'oeilkunsten". Blændværker. Gijsbrechts. Kongens Illusionsmester. Statens Museum for Kunst. København 1999, pp. 49-75.

Bätschmann, Oskar: "Anleitung zur Interpretation: Kunstgeschichtliche Hermeneutik". Kunstgeschichte. Eine Einführung. Ed. Hans Belting o.a. Berlin 1996, pp. 192- 222.

Foucault, Michel: The Order of Things. An Archaeology of the Human Sciences. 1970, 1997.

Gammelbo, Poul: "Cornelius Norbertus Gijsbrechts og Franciscus Gijsbrechts". Kunstmuseets Aarsskrift XXXIX-XLII. København 1956, pp. 125156.

Gundestrup, Bente: Det kongelige danske Kunstkammer 1737 / The Royal Danish Kunstkammer I-III. København 1991-95.

Gundestrup, Bente: "Kunstkammeret og Albert Eckhouts malerier" i Nordisk Museologi 2004.1, pp. 43-58 (engelsk resume).

Hein, Jørgen: "Das Grüne Kabinett im Schloss Rosenborg - Schatzkammer oder Raritäten-Kabinett?" Macrocosmos in Microcosmo, Die Welt in der Stube. Zur Geschichte des Sammelns 14501800, ed. Andreas Grote. Opladen 1994, pp. 323-337. 
Hein, Jørgen: "Ein wiederentdeckter Elfenbeinpokal: Fragen nach möglichen Auftraggebern." Im Blickfeld. Georg Hinz. Das Kunstkammerregal. Udstillingskatalog, red. Christoph Heinrich. Hamburg 1996, pp. 27-34.

Hein, Jørgen: "Collecting in Prague and Copenhagen". Rudolf II, Prague and the World, ed. L. Konecky, B. Bukovinská og I. Muchka. Prag 1998.

Hein, Jørgen: "Illusion og virkelighed. - malerier og genstande". Blændværker. Gijsbrechts. Kongens Illusionsmester. Statens Museum for Kunst. København 1999, pp. 75-91.

Heinrich, Christoph: Im Blickfeld. Georg Hinz. Das Kunstkammerregal. Udstillingskatalog. Hamburg 1996, pp. 27-34.

Inventarium over Kunst- Raritet- og Model-Kammeret. 1674. Rigsarkivet (kopi på Statens Museum for Kunst, arkiv).

Inventarium over "Hans Kongl. Maysts Kunst og Raritet Kammer" v. Holger Jacobæus. 1689.

Inventarium, Registrering ofver Hans Kongl. Mayst Konst og Raritet-Kammer. 1690 (Rigsarkivet, Nationalmuseet, kopi Statens Museum for Kunst, arkivet).

Jacobæus, Holger: Museum Regium. København 1696.

Jongh, E. de: Still-Life in the age of Rembrandt. Udstillingskatalog, Auckland City Art Gallery 1982.

Journal. "Kunst-Kammeret i Kiøbenhavn". 1771, pp. 1-7.

Jönsson, Hanne: "Breve på en bræddevæg. Trompe l'oeil. 1668". 100 Mesterværker. Statens Museum for Kunst, ed. Eva Friis. København 1996, p. 82.

Koester, Olaf: Vanitas. Filosofiske Billeder. Udstillingskatalog. København 1995.

Koester, Olaf: Blændværker. Gijsbrechts. Kongens Illusionsmester. Statens Museum for Kunst. København 1999.

Köhler, Johan: Anweisung für Reisende Gelehrte, Bibliothecken, Müntz-Cabinette ... Kunstkam- mern u.d.m. mit Nutzen zu besehen. Frankfurt,

Leipzig 1762.

Körner, H. et al. (ed.): Nachahmung der Natur. Herkunft und Implikation eines Topos. Die Trauben des Zeuxis. Formen künstlicher Wirklichkeitsanneigung. Hildesheim 1990.

Liedtke, Walter A.: "Faith in Perspective. The Dutch Church Interior." Connoiseur 1976, October, pp.127-133.

Liedtke, Walter A.: Architectural Painting in Delft. Doornspijk 1982.

Liisberg, H.C. Bering: Kunstkammeret - dets stiftelse og ældste Historie. København 1897.

Liisberg, H.C. Bering: Rosenborg og Lysthusene i Kongens Have. København 1914.

MacGregor, Arthur: "Die besondern Eigenschaften der 'Kunstkammer'". Macrocosmos in Microcosmos. Die Welt in der Stube. Zur Geschichte des Sammelens 1450-1800. Ed. Andreas Grote. Leske, Budrich, Opladen 1994, pp. 61-107.

Marquard, Emil: Kongelige Kammerregnskaber fra Frederik IIIs og Christian Vs Tid. København 1918.

Montias, J.M.: "'Perspectives' in 17th Century Inventories". Perspectives: Saenredam and the architectural painters of the 17th century. Udstillingskatalog Museum Boymans-van Beuningen Rotterdam. 1991, pp. 19-31.

Stoichita, Victor I.: The Self-Aware Image. An Insight into Early Modern Meta-Painting. Cambridge og New York 1997.

Thura, Laurids de: Hafnia Hodierna, Eller Udførlig Beskrivelse om den Kongelige Residens - og Hoved-Stad Kiøbenhavn. København 1748.

\section{SUMMARY}

This article takes a historical approach that aims to reconstruct the original first room - The Perspective Chamber - in The Royal Kunstkammer in Copenha- 
gen, Denmark, and to discuss whether it was planned from the outset as a coherent and meaningful decoration, in which C. N. Gijsbrecht's paintings formed a natural part.

In 1690 , the first inventory was made of the new Kunstkammer, which had been located in the Castle of Copenhagen until the late 1680s. A new building, which subsequently housed the Royal Library, the Arsenal and the Kunstkammer, had been under construction since 1665 and was still being built during Gijsbrecht's stay in Copenhagen in 1668-1672.

This article reconstructs the original decoration of the Perspective Chamber on the basis of the inventory from 1690, supplemented by the inventory of 1737 , which is in part more elaborate and descriptive. The first items listed are five perspective boxes, three of which are preserved in the National Museum of Denmark in Copenhagen. The Perspective Chamber's decoration also consisted of paintings with architectural motifs, still lifes and trompe l'oeils. With a few exceptions, we cannot tell which of Gijsbrecht's paintings were included in the Perspective Chamber since the entry in the 1690 inventory only says "Twelve nice pieces with numerous figures by Cornelio Gübsbrecht". A journal from 1771 mentions that Gijsbrecht's letter racks or Quodlibets "betray the eye". The article shows how some of Gijsbrecht's paintings of both letter racks and trompe l'oeil cupboards feature items that would normally be displayed in a kunstkammer. Some of Gijsbrecht's paintings are actually representations of Kunstkammer cupboards. It is tempting to assume that these paintings were made for the Perspective Chamber.

Finally, the article sets the Perspective Chamber and its trompe l'oeils in a context of the Baroque mentality, when the trompe l'oeil was seen as one of the period's most typical phenomena. In this respect, Gijsbrecht's paintings express an essential "vein" of their time. If we assume that the paintings with Kunstkammer references were those actually displayed in the Perspective Chamber, we can see that they also represent a way of organising the microworld of the kunstkammer, which is anchored in the Renaissance navigation within the elements of resemblance, similitude and correspondence: a Kunstkammer exposes paintings representing kunstkammers and kunstkammer objects, or issues related to the things exposed in a kunstkammer. In this respect, the presence of Gijsbrecht's paintings in the Kunstkammer could also be said to represent a somehow anachronistic way of thinking.

Eva de la Fuente Pedersen

Museumsinspektør, Seniorforsker

Senior Research Curator, Ph.D.

Den Kongelige Maleri-og Skulptursamling

Collection of Paintings and Sculpture

Eeva.pedersen@smk.dk

T 4533748532

Sølvgade 48-50, DK-1307 København K 